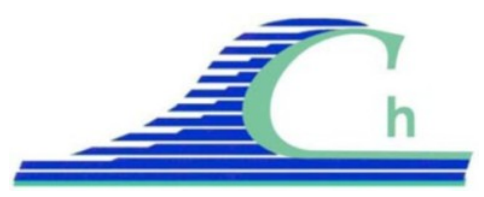

XII ${ }^{\text {imes }}$ Journées Nationales Génie Côtier-Génie Civil

Cherbourg, 12-14 juin 2012

DOI:10.5150/jngcgc.2012.114-L @ Editions Paralia CFL

disponible en ligne - http://www.paralia.fr - available online

\title{
A civil engineering application in sediment management: A confined embankment in Cherbourg harbour
}

\author{
Daniel LEVACHER ${ }^{1}$, Michel PIOLINE ${ }^{2}$, Martin SANCHEZ ${ }^{3}$, Eric TISON $^{4}$ \\ 1. Université de Caen, GRGCE, UMR 6143 CNRS - M2C, 24 rue des Tilleuls, \\ 14000 Caen, France. \\ daniel.levacher@unicaen.fr
}

2. Département de Géotechnique, CETE Normandie-Centre, 10 chemin de la Poudrière, BP 245, 76121 Le Grand-Quevilly Cedex Rouen, France.

michel.pioline@developpement-durable.gouv.fr

3. Université de Nantes, LPGN, UMR 6112 CNRS, BP 92208, 44322 Nantes, France. martin.sanchez@univ-nantes.fr

4. Ports Normands Associé, 50100 Cherbourg-Octeville, France.

e.tison@pna-ports.fr

\begin{abstract}
:
This paper concerns a beneficial use for sustainable marine sediment management taking into account the proximity of the application, i.e. the minimal distance from dredging of sediments to the implementation. Marine fine sediments concerned are dredged from two basins of Cherbourg harbour in Normandy (West of France). After sampling, the sediments have first been characterized so as to obtain their physical and chemical properties which constitute a part of the sediment identity card. Based on these properties, port authorities have investigated solutions to reuse them as construction material. A harbour quay level or platform was considered for the Port of Cherbourg for a volume of $30000 \mathrm{~m}^{3}$ of dredged sediments. An earthwork reusing this volume was built in Cherbourg's port of commerce area. It was a confined embankment, around $100 \times 100 \mathrm{~m}^{2}$, inserted in a $3 \mathrm{~m}$ deep excavation. This confined structure was filled with the raw sieved sediments dredged from two basins of Cherbourg harbour. A 3metre high layer of coarse and gravelly soil has overloaded the sediments layer so as to consolidate it. The hydraulics properties needed for this earthwork project are given. Its technical design and surveying conditions are described. Another potential beneficial use for these marine sediments was also considered similar to a material for sub layers in road structure. The sediments might be dehydrated first and mixed with different additions of lime. Many mixtures were tested and from the obtained results it was decided to build a quay platform. Part of the structure was built and during its construction, an experimental investigation to compare sediment behavior under on site and in laboratory consolidation was performed. Results of testing in laboratory are detailed here and the different steps of the investigation are given. The geotechnical properties and parameters useful for the project are first given, some details of
\end{abstract}


construction are presented and finally a comparative analysis as experimental return is partially outlined.

Keywords: Dredged sediment - Sediment properties - Settlement parameters Beneficial use - Confined embankment - Sediment management

\section{Introduction}

Sediment management is a challenge for port authorities that are faced to the French standards and rules of application. If damping at sea is maintained under some environmental conditions (MATE, METL, 2000), the deposit or storage on land poses a problem due to the fact that the dredged sediments might be considered as waste materials. So investigations for beneficial reuses are strongly recommended i.e. valorization of marine sediments constitutes an important issue in the management of the latter. If recent research works are focused on the stabilization/solidification $\mathrm{S} / \mathrm{S}$ processes using binders, their application first concerns road materials (COLIN, 2003; LEMEE, 2006; DUAN, 2008; LIMEIRA, 2011). Some of these appear as technically inapplicable for reasons of implementation as the dewatering of sediments from a water content of $200 \%$ to $50 \%$ before mixing, the absence of space to store or to spread the sediments on land, the cost of binders and additives. Even if a S/S cement-based with lime treatment was suggested, Cherbourg port authority chose the filling of an excavation with the $30000 \mathrm{~m}^{3}$ dredged sludge re-used in fill, thus constituting a confined layer of material for a harbour quay platform, LEVACHER \& PIOLINE (2011). For this type of embankment, a geotechnical characterization, partially reported here, was performed so as to obtain physical, chemical and hydraulic properties of the dredged sediments and the undrained shear strength evolution. The concept of the earthwork is presented and the phases of construction are detailed as well as part of the instrumentation in site.

As mentioned above a series of tests using a $\mathrm{S} / \mathrm{S}$ technique with lime-based treatment was undertaken for a beneficial use of this dredged marine sediment as an alternative material. Usually as cited in literature, this kind of S/S process without cement and additives does not improve sufficiently the mechanical performance. So as to obtain higher performance in accordance with the standards (LCPC \& SETRA, 1992), mixtures with cement-lime plus additives (fly ash, silica fume) and addition of fine are suggested (BEHMANESH, 2009; SILITONGA et al, 2010; LIMEIRA, 2011). Even if the sediment-lime mixtures have revealed here unsuccessful results, some of them are reported with details relative to the preparation and laboratory testing. 


\section{XII ${ }^{\text {èmes }}$ Journées Nationales Génie Côtier - Génie Civil \\ Cherbourg, 12-14 juin 2012}

\section{The harbour quay platform study}

\subsection{Harbour dredged sediments}

Sediments dredged in different parts from 2 harbour basins (AP and BF) with a Van Veen manual dredger were stored in sealed plastic barrels. Physical and chemical properties are determined in the laboratory according to the French standards. Table 1 summarizes them. The high level of water content varies from 100 to $200 \%$, which corresponds to the values obtained with a mechanical dredger. Presence of organic matters between $10-21 \%$ and a high water content make the application of a cementbased $\mathrm{S} / \mathrm{S}$ process on raw sediments difficult. The lower solid particles density $2.38 \mathrm{t} / \mathrm{m}^{3}$ corresponds to the high level of organic matters $(21 \%)$, so the average value obtained is $2.52 \mathrm{t} / \mathrm{m}^{3}$. A useful value of $2.55 \mathrm{t} / \mathrm{m}^{3}$ is commonly used for organic mud. Sediments are sieved to eliminate the coarse shell debris and a granulometry analysis is undertaken with a Coulter granulo-laser. Considering the grain size distribution, the average grain size $\mathrm{d}_{50}$ nears $15 \mu \mathrm{m}$ and $32 \mu \mathrm{m}$ respectively for the BF and the AP basins. If the $\mathrm{d}_{90}$ varies only between $100-200 \mu \mathrm{m}$, the Cherbourg sediments re ranged between 0 and 2 $\mathrm{mm}$ material due to the presence of sand particles in some samples. The texture corresponds to a silty sandy fine soil. The silt fraction given in table 1 is up to $64 \%$ while the clay fraction does not exceed $10 \%$.

Table 1. Typical properties for the dredged sediments.

\begin{tabular}{lcc}
\hline Sediment reference & $\boldsymbol{A P}$ & $\boldsymbol{B F}$ \\
\hline Clay fraction $(<2 \mu \mathrm{m})(\%)$ & $3.4-3.7$ & $6.1-8.5$ \\
Silt fraction $(2$ à $63 \mu \mathrm{m})(\%)$ & $64.3-67.3$ & $74.3-75.8$ \\
Sand fraction $(>63 \mu \mathrm{m})(\%)$ & $29.0-32.0$ & $15.7-19.5$ \\
$d_{10}(\mu \mathrm{m})$ & $4.8-5.2$ & $2.3-3.1$ \\
$d_{50}(\mu \mathrm{m})$ & $32.0-32.5$ & $12.8-17.2$ \\
$d_{90}(\mu \mathrm{m})$ & $136.2-192.9$ & $100.0-113.6$ \\
Initial water content $w(\%)$ & $136-152$ & $106-200$ \\
Liquidity Limit $L_{L}(\%)$ & $91-103$ & $72-122$ \\
Plasticity index $I_{P}(\%)$ & $40-51$ & $16-66$ \\
Methylene blue value $(g / 100 g)$ & \multicolumn{2}{c}{$1.0-1.9$} \\
Organic matter content $(\%)$ & \multicolumn{2}{c}{$10-21$} \\
Solid particles density $\left(t / \mathrm{m}^{3}\right)$ & \multicolumn{2}{c}{$2.36-2.64$} \\
\hline
\end{tabular}

The highest methylene blue values 1.6-1.9 obtained concern the surficial. The total range of the values from 1.0 to 1.9 is adequate for the fine soils classification. Atterberg limits bring other elements to classify these fine soils very sensitive to water. The average liquidity limit $\mathrm{L}_{\mathrm{L}}$ and plasticity index values are respectively $97 \%$ and $41 \%$ $45.5 \%$. Some homogeneity is observed for the AP basin as shown in figure 1 in which the different values are reported in the conventional Casagrande diagram. Note that the BF basin average values are centred on the AP basin ones. The liquidity limit $\mathrm{L}_{\mathrm{L}}$ values 
increase with the percentage of fine particles in the samples. All these Atterberg limits results are in accordance with the organic fine soils. Referring to figure 1, Cherbourg sediments are defined as high plastic organic silty fine soils. Referring to the French guide for roads and embankments (LCPC \& SETRA, 1992), these sediments could be ranged in fine soils from class A2 to A4.

The important organic matters content certainly influence the determination of methylene blue values which are not so high. The fine soil texture and the organic matters have a predominant role in the sediments behaviour as well as in a cementbased S/S process or in the consolidation of any embankment made up with it. The two types of beneficial reuse (i) sub road layer material, (ii) filling embankment material, were considered by Cherbourg port authorities for a total volume of $30000 \mathrm{~m}^{3}$ of sediments dredged from the AP and BF basins.

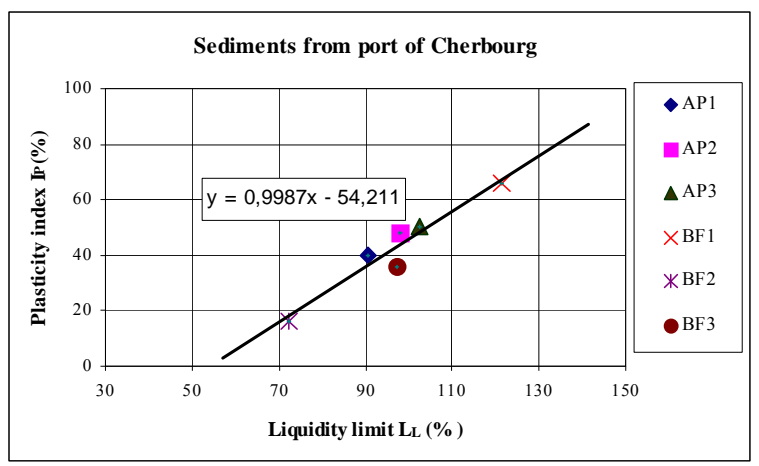

Figure 1. IP vs WL in Casagrande diagram.

\subsection{Lime based stabilization of sediments}

Addition of lime to the sediments was suggested in a stabilization process while knowing the following effects (i) immediate decreasing of water content of sediments, (ii) improvement of workability for the lime-sediment composite, (iii) obtaining a possible long term mechanical performances, and (iv), attenuation of the effects due to the organic matters effects. Taking into account the economical point of view, sediment-lime mixtures were performed with an addition of $3 \%$ and $6 \%$ of lime. These percentages are expressed in function of dry sediment matters. As the focused application was a reuse for sub layer for roads, the mechanical indicators considered are the unconfined compressive strength UCS and Brazilian tensile strength BTS at 28 days. The parameters for molding and manufacturing cylindrical (height/diameter $=2$ ) samples have been chosen according to compaction tests i.e. a water content of $35 \%$ and $1.3 \mathrm{t} / \mathrm{m}^{3}$ for dry density. The maturation period was 28 days according to the French standards at 2 temperatures: $20^{\circ} \mathrm{C}$ and $60{ }^{\circ} \mathrm{C}$. The samples $(50 \mathrm{~mm}$ diameter, $100 \mathrm{~mm}$ height) after a static compaction were preserved in sealed plastic tubes. All samples were tested at 28 days so as to obtain the mechanical resistances and to compare them with the immediate ones obtained after the compaction, see the results in table 2. 


\section{XII ${ }^{\text {èmes }}$ Journées Nationales Génie Côtier - Génie Civil \\ Cherbourg, 12-14 juin 2012}

The lime addition reacts immediately giving double the $\mathrm{UCS}_{0}$ without lime. For an addition of $3 \%$ at 28 days and at $20{ }^{\circ} \mathrm{C}$, the improvement ratio $\mathrm{I}_{\mathrm{R}}$ defined as $\mathrm{UCS}_{28} / \mathrm{UCS}_{0}$ nears only 2.2. The short-term lime reactivity appears very low or the organic matters disturb it. So, $I_{R}$ reaches 4.6 when $6 \%$ of lime is added. Usually, the temperature is revealed as an activation factor in the pozzolanic reactions with lime. But here, results obtained on samples at $60{ }^{\circ} \mathrm{C}$ do not confirm this effect. Considering the BTS values, the improvement is not evident, except if the temperature and the level of addition are combined: $60{ }^{\circ} \mathrm{C}$ and $6 \%$ of lime. With these conditions, $\mathrm{I}_{\mathrm{R}}\left(\mathrm{BTS}_{28} / \mathrm{BTS}_{0}\right)$ equals to 4.6. Referring to the results obtained, a lime-based mixture with $6 \%$ would give the best resistances and assuming the development of long term pozzolanic reactions, then, resistances might be higher. So, many disadvantages can be listed to this suggested stabilization: (i) the techniques and coast of the sediments, dewatering of $30000 \mathrm{~m}^{3}$, from $100 \%-200 \%$ to $35 \%$, the recommended water content, (ii) the cost of lime addition, (iii) the minimal UCS value for any application in road construction is 1 MPa before durability tests, (iv) temperature effect cannot be considered for site construction.

Dehydrating the sediments was technically and financially impossible for the port authorities who decided to made a harbour quay platform with the filling of the 30000 $\mathrm{m}^{3}$ of raw sediments. The natural dewatering was abandoned because no space was available in the harbour area. If we consider climatic conditions, the sediment layers have to be covered in order to dry.

Table 2. UCS resistances of the lime-based stabilization with the dredged sediments.

\begin{tabular}{|c|c|c|c|}
\hline Lime addition (\%) & 0 & 3 & 6 \\
\hline \multicolumn{4}{|c|}{ Unconfined Compressive Strength (MPa) } \\
\hline Immediate $U C S_{0}$ & 0.320 & 0.602 & 0.632 \\
\hline$U C S_{28}$ at 28 days $-20^{\circ} \mathrm{C}$ & - & 0.690 & 1.337 \\
\hline$U C S_{28}$ at 28 days $-60^{\circ} \mathrm{C}$ & - & 0.376 & 1.178 \\
\hline \multicolumn{4}{|c|}{ Brazilian Tensile Strength (MPa) } \\
\hline Immediate $\mathrm{BTS}_{0}$ & 0.012 & 0.018 & 0.019 \\
\hline $\mathrm{BTS}_{28}$ at 28 days $-20^{\circ} \mathrm{C}$ & - & 0.013 & 0.028 \\
\hline $\mathrm{BTS}_{28}$ at 28 days $-60^{\circ} \mathrm{C}$ & - & 0.021 & 0.055 \\
\hline
\end{tabular}

\subsection{Hydraulic properties of dredged sediments}

\subsubsection{Materials and methods}

The hydraulic properties are obtained by the techniques used for the studies of sedimentation and consolidation of saturated fine grained soils. These properties provide the parameters necessary to the settlement calculations for the filling of embankments by the sediments. The relationship between the permeability $k$ and the solid matter concentration $C$ is very useful. 
The decantation tests are carried out for different initial concentrations from 200 to 500 $\mathrm{g} / \mathrm{l}$. This range is representative of the sediments concentrations obtained with the dredging techniques. The column of decantation test consists in filling a mixture of fine homogeneous sediments at an initial concentration $C_{\mathrm{i}}$ in a transparent tube with an outer diameter of $54 \mathrm{~mm}$, thickness of $2 \mathrm{~mm}$ and total height of $2 \mathrm{~m}$ for the low concentrations, or in other tubes with the following characteristics: outside diameter 94 $\mathrm{mm}$, thickness of $3 \mathrm{~mm}$ and height of $2 \mathrm{~m}$. During the process of sedimentation, the evolutionof the height of the sample is followed according to time by close measurements for the first six hours: $30 \mathrm{~s}, 1 \mathrm{mn}, 2 \mathrm{mn}, 4 \mathrm{mn}, 6 \mathrm{mn}, \ldots 30 \mathrm{mn}, 35 \mathrm{mn}, 40$ $\mathrm{mn}, \ldots$ 1h00, 1h10, 1h20, ... and 2h00, 2h20, 2h40, 3h00, 3h30, 4h00, 5h00, 6h00, $24 \mathrm{~h} 00$, then every 24 hours. The period of observation was 10 to 30 days, see figure 2 . In the absence of effective stresses, the sedimentation velocity $V_{s}$ of fine sediments resting on an impermeable bottom (negative to indicate a fall) under the action of its own weight can be calculated using the following relation of BEEN (1980):

$V_{s}=-\frac{k}{\rho_{s}}\left[\frac{\rho_{s}}{\rho_{o}}-1\right] C$

In which $\rho_{s}$ is the density of the solid phase $\left(\approx 2.55 \mathrm{t} / \mathrm{m}^{3}\right.$ for an organic fine sediment), $\rho_{o}$ is the density of water $\left(1 \mathrm{t} / \mathrm{m}^{3}\right), C$ is the dry matter concentration (ratio of the solid mass on total volume), $k$ is the coefficient of permeability. Knowing that the coefficient of permeability of a fine sediment depends on its concentration, the theory of sedimentation of KYNCH (1952) is compatible with the formulation of BEEN (1980). The research works completed by SANCHEZ (2000) shows that in the case of fine sediments, the relation between $k$ and $C$ frequently obeys the following empirical law:

$k=A_{1} \exp \left(-A_{2} \frac{C}{\rho_{s}}\right)$

Where, $A_{1}\left(\mathrm{~m}_{\mathrm{s}} \mathrm{s}^{-1}\right)$ and $A_{2}$ are specific parameters for each fine sediment. The parameters of this law can be deduced from the experimental curves of sedimentation by a graphic method developed by KYNCH (1952) and modified by SANCHEZ \& GROVEL (1993). Consolidation testing under vertical load was also performed with standard oedometer cells used in soil mechanics. For the Cherbourg marine sediments, samples were loaded under the following stresses: $12.5 \mathrm{kPa}$, then $25,50,100$, and $150 \mathrm{kPa}$.

\subsubsection{Sedimentation and consolidation parameters}

The decantation tests in columns carried out on varying concentrations, 200-300 g/1, in series $\mathrm{B}$, show that the fine sediments from the 2 basins have the same sedimentation behaviour, see figure 2. For two test sedimentation series and different initial concentrations, the evolution of the permeability coefficient $k$ and $C$ can be drawn, see figure 3. The oedometric tests have provided the consolidation parameters (compression coefficient, consolidation coefficient, creep coefficient) and allowed to obtain other data 


\section{XII ${ }^{\text {èmes }}$ Journées Nationales Génie Côtier - Génie Civil \\ Cherbourg, 12-14 juin 2012}

for the $k$ - $C$ relation. Thus, figure 4 shows the variation of the coefficient of permeability $k$ with the void ratio $e$ for the whole of the sedimentation (high initial void ratio) and consolidation tests. We observe the continuity of the evolution for Cherbourg's sediments. The consolidation coefficient $C_{v}$ has been deduced from the settlement-time curves. Some variations were observed with the different loadings, see figure 5. For the AP basin and for Mix (mixed) sediments, values of $C_{v}$ tend to the same values which is different for the BF basin values. So, $C_{v}$ values become constant over a $50 \mathrm{kPa}$ applied consolidation stress.

The presence of organic matters could induce secondary consolidation. So creep tests under a $400 \mathrm{kPa}$ applied consolidation stress were run out to determine, for the raw sediments, the coefficients of creep $C_{a e}$ which are defined as follows:

$$
C_{\alpha e}=\frac{-\Delta e}{\Delta \log (t)}
$$

Where $C_{\alpha e}$ is the creep coefficient, $\Delta \mathrm{e}$ the void ratio variation and $\Delta \log (t)$ the increase of the time logarithm. Finally, table 3 gathers the consolidation and creep parameters for the Cherbourg sediments used for the project of quay platform. Note that a compression index of 0.2 corresponds to the limit between the low and the compressible soils; a value $>0.4$ indicates that the soil is very compressible. Here these soils are made up of fine and organic sediments.

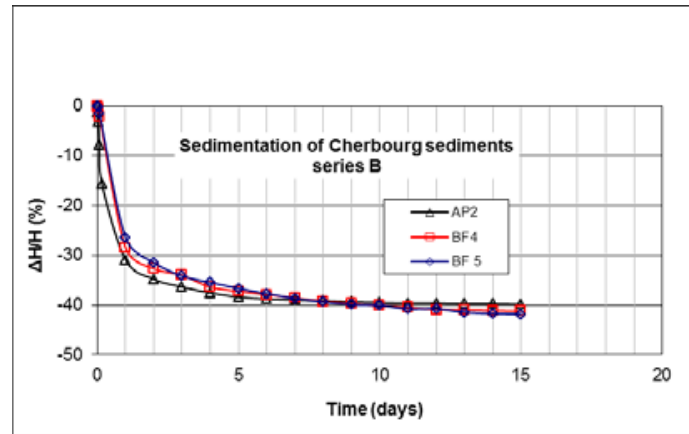

Figure 2. Examples of sedimentation curves, $(\Delta H / H$ relative height in \%).

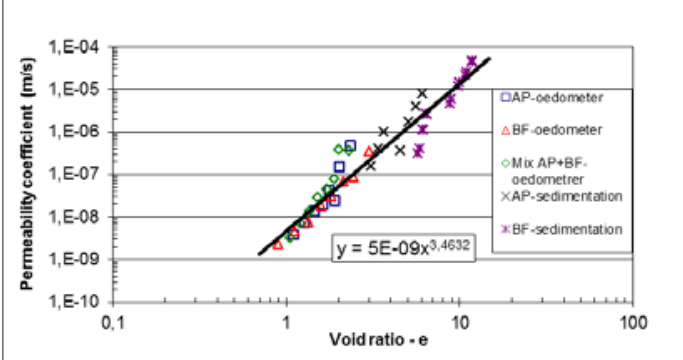

Figure 4. k-e relationships issued from oedometer and sedimentation tests.

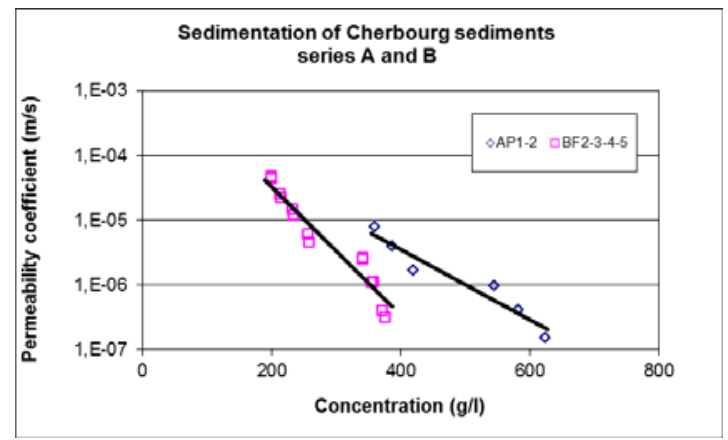

Figure 3. $k$-C relationships for $A P \& B F$ sediments.

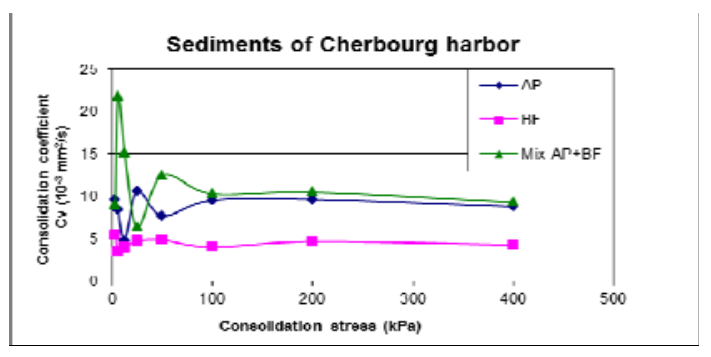

Figure 5. Consolidation coefficient $\mathrm{Cv}$ for the dredged sediments. 
Table 3. Settlement parameters for the dredged sediments.

\begin{tabular}{lcc}
\hline Raw sediments & $\boldsymbol{A P}$ & $\boldsymbol{B A F}$ \\
\hline Compression index $C_{c}$ & 0.5114 & 0.8368 \\
Consolidation coefficient $C_{v}$ & 0.0092 & 0.0043 \\
$\left(\mathrm{~mm}^{2} / \mathrm{s}\right)$ & 0.019 & 0.020 \\
${\text { Creep index } C_{\alpha e}}$ & & \\
\hline
\end{tabular}

\subsubsection{Undrained shear strength of the sediments}

Measurements of $C_{u}$ have been performed so as (i) to define the undrained shear strength- water content relation and (ii) to determine the possibility to move on the sediments layer to sew and seal the geosynthetics membrane to confine the layer. Part of the measurements have been run out in laboratory with a vane shear test and fall cone. For the fall cone measurements some corrections were made according to the recommendations of BJERRUM, see table 4, (BJERRUM, 1954), i.e. the fall cone values are multiplied by a factor $\beta$ as follows:

$\tau_{\text {fréelle }}=\beta \times \tau_{\text {fmeasured }}$

Table 4. Recommended values of $\beta$ after BJERRUM (1954).

\begin{tabular}{ll}
\hline Fine soils & Coefficient $\beta$ \\
\hline Fluid mud, peat & 0.6 \\
Clayey mud & 0.7 \\
Soft clay & $0.8-0.9$ \\
Clay & 1.0 \\
\hline
\end{tabular}

Cherbourg sediments have been considered like muds and a coefficient $\beta$ chosen between 0.6-0.7 to correct the fall cone values which are reported on figure 6 . The $w-C_{u}$ relationships obtained in laboratory have been completed with vane shear test performed on site, directly on the top of the layer in 17 points through the layer. These in situ measurements have been made at a depth corresponding to half the thickness of the layer with a water content measurement. The in-situ values obtained are in accordance with the laboratory values as shown in figure 6 .

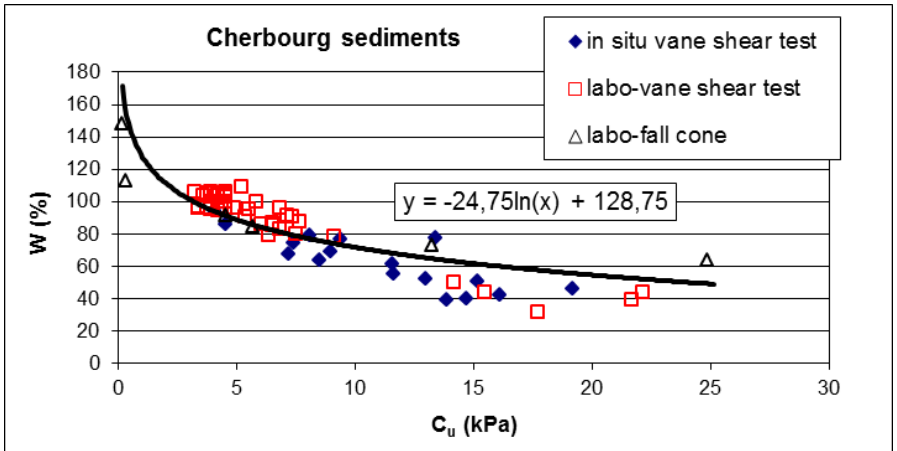

Figure 6. $W$-Cu relationships for the Cherbourg sediments 


\section{XII ${ }^{\text {èmes }}$ Journées Nationales Génie Côtier - Génie Civil \\ Cherbourg, 12-14 juin 2012}

(on site and in laboratory measurements).

The limit conditions of the layer in-site and for the laboratory samples were the same, namely, drainage was possible on the two surfaces. A continuous decreasing is observed, which could be expressed by an exponential relation as given in figure 6 .

\subsection{A quay platform project}

The final project as a quay platform is located in a part of the port of Commerce of Cherbourg named "Terre-plein des Mielles". It consists in a $3 \mathrm{~m}$ deep excavation from level $+4.50 \mathrm{~m} \mathrm{CM}$ to $+7.50 \mathrm{~m} \mathrm{CM}(\mathrm{CM}$ is the referential marine height in France, expressed in metre). A side of the excavation of $100 \mathrm{~m}$ long is the limit between the sea and the platform. This side was built as a small dyke up to a level of $+7.80 \mathrm{~m} \mathrm{CM}$. The area corresponds to $100 \times 100 \mathrm{~m}^{2}$ plan separated in 2 sections.

The bottom is constituted of 3 layers: two external geotextiles, the medium geotextile is a filtering geo membrane (on sides) and a $2 / 4$ or $2 / 6 \mathrm{~mm}$ gravel layer with a thickness of $0.50 \mathrm{~m}$ above the filtering geo membrane and of $0.20 \mathrm{~m}$ under this latter (in the bottom). A draining trench was installed to collect the waters before treating. All geotextiles and geomembrane layers were attached on the external sides of the excavation before filling as shown on figure 7.

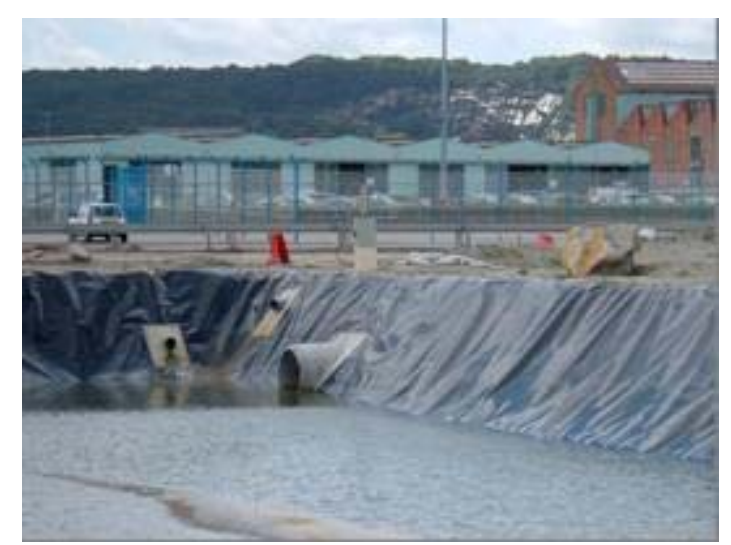

Figure 7. A vertical scheme of the excavation.

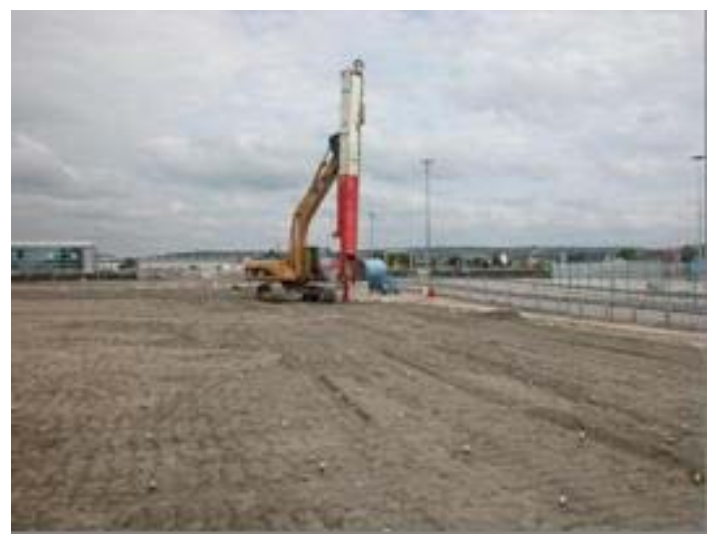

Figure 8. A sketch of the geodrains implementation.

\subsubsection{The planning of construction}

The different steps of the platform construction are summarized as follows (i) dredging operations during 2 months; (ii) filling operations in the same time of dredging ones, (iii) self-weight consolidation of the dredged sediments during 6 months, (iv) setting up of the geotextile for covering, of a sand layer up to the covering geotextile, of the vertical flat plastic drains (see figure 8 , geodrains installation) and the $3 \mathrm{~m}$ height of earth layer to load the layer of sediments for consolidating during one year and more. 


\subsubsection{The proposed experimental set-up on site}

The aim of the experimental set upon site was to compare the sediment consolidation behaviour in the excavation place and in laboratory. The waited results interests in the properties of self-weight consolidation (evolution of water content, bearing capacity), the settlement during consolidation under loading, the creep velocity and amplitude, the undrained shear resistance evolution.

\subsubsection{Measurements on site during construction}

A set up of measurements have been performed on site so as to get some data useful for comparing the self-weight and loading consolidation marine sediment behaviour. Taking into account the inherent difficulties to run out these measurements on the sediment layer before loading, an investigation program was proposed and consisted in (i) settlement measurements obtained by special settlement plates disposed on the top of the sediment layer. These plates support tubular pipes which pass through the $3 \mathrm{~m}$ high load earth layer, (ii) water content measurements by sampling of marine sediment during the settlement. These measurements were run to evaluate the homogeneity of the 2 filled sections of the platform, (iii) vertical profiles of undrained shear resistance using vane shear testing.

\subsubsection{The planning of experimental investigation}

The installation of the different settlement plates requires some reference operations:

- Step 1: After the pose of the covering geotextile and before adding any loading layer, some topographic profiles ( 3 cross and 1 long ones) were run out. These settlement measures were representative for the self-weight consolidation. Then 4 or 5 selected points have been chosen for each plane section in order to core sediment (water content measurements) and to perform vane shear testing every $0.50 \mathrm{~m}$ depth (undrained shear resistance profile, see figure 9). Near these selected points steel plates with vertical tubes were positioned to measure the settlement.

- Step 2: After setting up of a sand filter layer on the covering geotextile and before the pose of vertical plastic drains, a set of measures (settlement, undrained shear resistance, water content) has been made.

- Step 3: After the vertical drains installation and before the placement of the loading earth layer, a same number of settlement plates were installed in the centre of the grid of drains, near the selected point of measures (step 1), A new complete set of measurement were operated.

- Step 4: A first loading earth layer was built on the sediment layer. At the end of the construction, another complete set of measurement were made.

- Step 5: At the end of the consolidation due to the first loading layer, all measurements were run before the disposal of the final loading layer. 


\section{XII ${ }^{\text {èmes }}$ Journées Nationales Génie Côtier - Génie Civil \\ Cherbourg, 12-14 juin 2012}

- Step 6: At the end of the consolidation of the embankment (2 layers), a final set of measurements were made.

Some of the on site results are reported and discussed by ZHANG (2007).
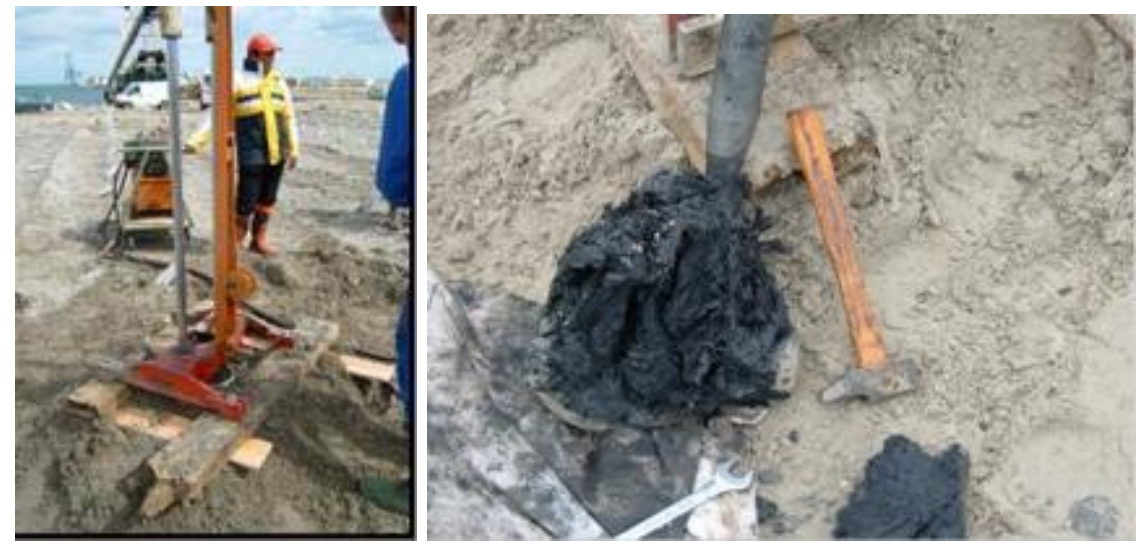

During operation testing (left) - Sediments around vane shear test blades (right)

Figure 9. Vane shear testing on the top of sediment layer.

\section{Conclusions}

The tests results obtained in laboratory and on site highlighted the feasibility of using dredged marine sediments in accordance with the characteristics of the constructive project: a quay platform. The experimental results show that the fine sediment studied can be successfully used and constitute a beneficial use as an alternative material for filling material in embankment without treating the marine sediments. This constitutes an innovative project and a volume of $30000 \mathrm{~m}^{3}$ of sediments were valorized.

\section{Acknowledgements}

The authors wish to acknowledge the financial support by IDRA Environnement Company (IDRA, 2005, Rennes, France) and by the DDE of Calvados (Caen, France).

\section{References}

BEEN K. (1980). Stress strain behaviour of a cohesive soil deposited under water. Ph.D. Thesis, Oxford University.

BEHMANESH J. (2008). Etude de la durabilité d'un sédiment traité au ciment et additifs. Ph.D. Thesis, Université de Caen, 215 p.

BJERRUM L. (1954). Geotechnical properties of Norwegian Clays. Norwegian Institute, Publ. No. 4, Oslo.

COLIN D. (2003). Valorisation de sédiments fins de dragage en technique routière. Ph.D Thesis, Université de Caen, 2003, 181 p. 
DUAN Z. (2008). Caractérisation, stabilisation et solidification de sédiments marins. Ph.D. Thesis, Université de Caen, 144 p.

IDRA (2005). Etudes physico-mécaniques des matériaux de dragage du port de Cherbourg en vue d'une utilisation en remblais. Rapport final, $134 \mathrm{p}$.

KYNCH G.F. (1952). A theory of sedimentation. Faraday Society Transactions, Vol. 48, pp 166-176. doi:10.1039/tf9524800166

LCPC, SETRA (1992). Guide Technique pour la réalisation des remblais et des couches de forme (GTR). Fascicule I, principes généraux.

LEMEE F. (2006). Traitement par alcali-activation de sédiments fins marins, non contaminés et à faible teneur en eau. Mise au point d'un procédé de stabilisation. $\mathrm{Ph} . \mathrm{D}$ thesis, Université de Caen, $187 \mathrm{p}$.

LEVACHER D., PIOLINE M. (2011). A recent civil engineering application in sediment management. Geo-Environmental Engineering 2011, Takamatsu, Kagawa, Japan, 21-22 May 2011, pp 127-134.

LEVACHER D., SANCHEZ M. (2011). Caractérisation de sédiments marins pour une mise en dépôt à terre et en remblai. European Journal of Environmental and Civil Engineering, EJECE, Vol. 15, nº 2, pp 167-178. doi:10.1080/19648189.2011.9693316

LIMEIRA J. (2011). The beneficial use of dredged marine sand as an alternative material for concrete. Ph D Thesis, Polytechnic University of Catalonia, Barcelona, $169 \mathrm{p}$.

MATE, METL -Ministre de l'aménagement du territoire et de l'environnement, Ministre de l'équipement, des transports et du logement- (2000). Arrêté du 14/06/00 relatif aux niveaux de référence à prendre en compte lors d'une analyse de sédiments marins ou estuariens présents en milieu naturel ou portuaire. J.O.R.F. $\mathrm{n}^{\circ} 184$ du 10 août 2000. pp 12415-12416.

SANCHEZ M., GROVEL A. (1993). Modélisation du tassement sous poids propre des couches de vase molle et saturée, sur un fond imperméable. La Houille Blanche, $\mathrm{n}^{\circ} 1$ pp 29-34. doi:10.1051//hb/1993002

SILITONGA E., LEVACHER D., MEZAZIGH S. (2010). Utilization of fly ash for stabilization of marine dredged sediments. European Journal of Environmental and Civil Engineering, EJECE, special issue "Génie Côtier", Vol. 14, n² 2, pp 253-265. doi:10.3166/ejece.14.253-265

ZHANG Z. (2008). Analyse et suivi de mesures sur site d'un terre-plein avec remblai constitué de sédiments de dragage. Master Report, Université de Caen, 50 p. 